\title{
Field relations, structure, and geochemistry of the Fisset Brook Formation in the Lake Ainslie - Gillanders Mountain area, central Cape Breton Island, Nova Scotia
}

\author{
S.M. Barr ${ }^{1}$, A.S. Macdonald ${ }^{1}$, A.M. Arnott ${ }^{*}$, and G.R. Dunning ${ }^{2}$ \\ 'Department of Geology, Acadia University, Wolfville, Nova Scotia BOP 1X0, Canada \\ ${ }^{2}$ Department of Earth Sciences, Memorial University of Newfoundland, \\ St. John's, Newfoundland A1B 3X5, Canada
}

Date Received June 12, 1995

Date Accepted October 31, 1995

\begin{abstract}
Detailed mapping shows that the Fisset Brook Formation in the Lake Ainslie - Gillanders Mountain area consists of a lowermost sedimentary unit overlain by basaltic and rhyolitic units. The sedimentary unit is mainly arkosic pebble conglomerate and siltstone, and unconformably overlies or is in faulted contact with older metamorphic and plutonic rocks. Scattered gabbroic plutons and dykes in the sedimentary unit are interpreted to represent "feeders" to the overlying basaltic flows. The basaltic unit consists mainly of subaerial flows, locally interlayered and intermixed with red-brown siltstone. The overlying rhyolitic unit consists mainly of eutaxitic to spherulitic flows or welded tuffs, with less abundant lapilli tuff. In the Lake Ainslie area, these rocks occur in a north-south array of rhombic fault blocks, whereas in the Gillanders Mountain area, the dominant structure is a large-scale anticlinal fold closing toward the south, cored largely by rocks of the Fisset Brook Formation. The chemical compositions of the basalt and rhyolite in both areas have been modified by alteration, but discrimination diagrams using relatively immobile elements, including rare-earth elements, indicate that the basalts and gabbros are continental, within-plate tholeiites. The rhyolites also have features indicative of origin in a within-plate setting, but are depleted in $\mathrm{Y}, \mathrm{Zr}$, and rare-earth elements compared to A-type granites. A rhyolite sample yielded a U-Pb (zircon) age of $373 \pm 4 \mathrm{Ma}$, thus indicating that the Fisset Brook Formation in the Lake Ainslie - Gillanders Mountain area is Middle to earliest Late Devonian in age, not Late Devonian to Early Carboniferous as previously inferred.
\end{abstract}

Une cartographie détaillée montre que la Formation Fisset Brook dans le secteur du lac Ainslie et du mont Gillanders est constituée d'une base sédimentaire recouverte d'unités basaltique et rhyolitique. La base sédimentaire est principalement formée d'un conglomérat de galets arkosiques et de siltstones; elle repose de façon discordante ou par contact faillé sur des roches métamorphiques et plutoniques. Les dykes et les plutons gabbroïques dispersés dans l'unité sédimentaire sont interprétés comme des "systèmes d'alimentation " des écoulements basaltiques sus-jacents. L'unité basaltique est principalement constituée d'écoulements subaériens, localement interstratifiés et entremêlés de siltstone brun rougeâtre. L'unité rhyolitique sus-jacente est essentiellement composée d'écoulements eutaxiques à sphérolitiques ou de tufs soudés, avec des conglomérats volcaniques à lapilli dans une matrice fine moins abondants. Dans le secteur du lac Ainslie, ces roches se présentent en une rangée nord-sud de blocs faillés rhombiques, tandis que dans le secteur du mont Gillanders, la structure dominante est un plissement anticlinal à grande échelle qui se referme vers le sud et qui abrite en son coeur une quantité substantielle de roches de la Formation Fisset Brook. Les compositions chimiques du basalte et de la rhyolite des deux secteurs ont été modifiées par altération, mais des schémas de discrimination utilisant des éléments relativement immobiles, dont des éléments de terres rares, révèlent que les basaltes et les gabbros sont des tholéiites intra-plaque continentaux. Les rhyolites possèdent en outre des caractéristiques qui témoignent qu'elles proviennent d'un cadre intra-plaque, mais elles sont pauvres en $\mathrm{Y}$, en $\mathrm{Zr}$ et en éléments de terres rares comparativement aux granites de type A. Une datation au $\mathrm{U}-\mathrm{Pb}$ (zircon) d'un échantillon de rhyolite lui a attribué un âge de $373 \pm 4 \mathrm{Ma}$, ce qui révèle que la Formation Fisset Brook du secteur du lac Ainslie et du mont Gillanders remonte à la période du Dévonien moyen au début du Dévonien supérieur, et non à celle du Dévonien supérieur au Carbonifère inférieur comme on l'avait auparavant laisser entendre.

[Traduit par la rédaction]

\section{INTRODUCTION}

The Fisset Brook Formation is distributed discontinuously in western Cape Breton Island in a zone extending

Present address: Department of Earth Sciences, Dalhousie University, Halifax, Nova Scotia B3H 3J5, Canada. north-south from Lowland Cove to the Creignish area (Fig. 1). The most extensive outcrop areas occur in the type section near Cheticamp (Kelley and Mackasey, 1965) and in the present area of study east of Lake Ainslie. In the latter area, volcanic and sedimentary rocks of the Fisset Brook Formation occur in faulted blocks just to the east of the lake 
and farther east in a more continuous area around Gillanders Mountain (Figs. 1, 2).

Previous work showed the general distribution of the Fisset Brook Formation in the Lake Ainslie - Gillanders Mountain area (Norman, 1933, 1935; Kelley and Mackasey, 1965; Huard, 1984), but was not in sufficient detail to enable subdivision of the formation into lithological units, or to interpret structural features. The purpose of this paper is to present the results of recent, more detailed, mapping, structural, and petrological studies of the Fisset Brook Formation in the Lake Ainslie - Gillanders Mountain area, as well as the first U-Pb (zircon) geochronologic data from the formation. This work is part of a detailed study of barite occurrences in the Lake Ainslie area (e.g., Macdonald, 1994), and of a larger study of Devonian - Carboniferous igneous activity in the Maritimes Basin (e.g., Barr et al., 1994).

\section{BACKGROUND}

The Fisset Brook Formation and possibly correlative units were recognized at scattered locations in Cape Breton Island by Kelley and Mackasey (1965). They considered the Fisset Brook Formation to be the lowermost formation of the Horton Group, a widespread Devonian to Carboniferous, mainly clastic sedimentary unit (e.g., Williams et al., 1985). However, some earlier (e.g., Neale, 1964) and most subsequent workers (e.g., Keppie, 1979; Smith and Macdonald, 1981) considered the formation to be separate from the overlying Horton Group. The age of the formation is generally cited rather imprecisely as Late Devonian - Early Carboniferous (e.g., Williams et al., 1985), because of conflicting paleontologic and radiometric evidenc, and uncertainty as to whether or not all the scattered areas included in the formation are of the same age (e.g., Blanchard et al., 1984).

Kelley and Mackasey (1965) established the type section in Fisset Brook in the Cheticamp area (Fig. 1), where the formation consists of a lower, mainly sedimentary unit, a middle unit described as predominantly andesitic, and an upper, predominantly rhyolitic unit. In a more detailed petrological study, Blanchard (1982) and Blanchard et al. (1984) described the Fisset Brook Formation as consisting of bimodal basalt-rhyolite suites with interlayered alluvial fan, lacustrine, and minor fluvial sedimentary rocks. They reported petrochemical data from the type area and elsewhere, including the Cooper Brook section in the Gillanders Mountain area, and interpreted the basaltic rocks to be tholeiitic, formed in an extensional tectonic regime. Huard (1984) reported similar conclusions based on petrochemical data mainly from the Lake Ainslie area.

\section{Field Relations in the STUdy area}

The Fisset Brook Formation in the area east of Lake Ainslie occurs along the western edges of a series of faultbounded basement blocks, in the north termed the Scotsville inlier and in the south the East Lake Ainslie inlier (Fig. 2). The blocks are surrounded by folded clastic rocks of the Horton Group, accompanied to the west by overlying car-

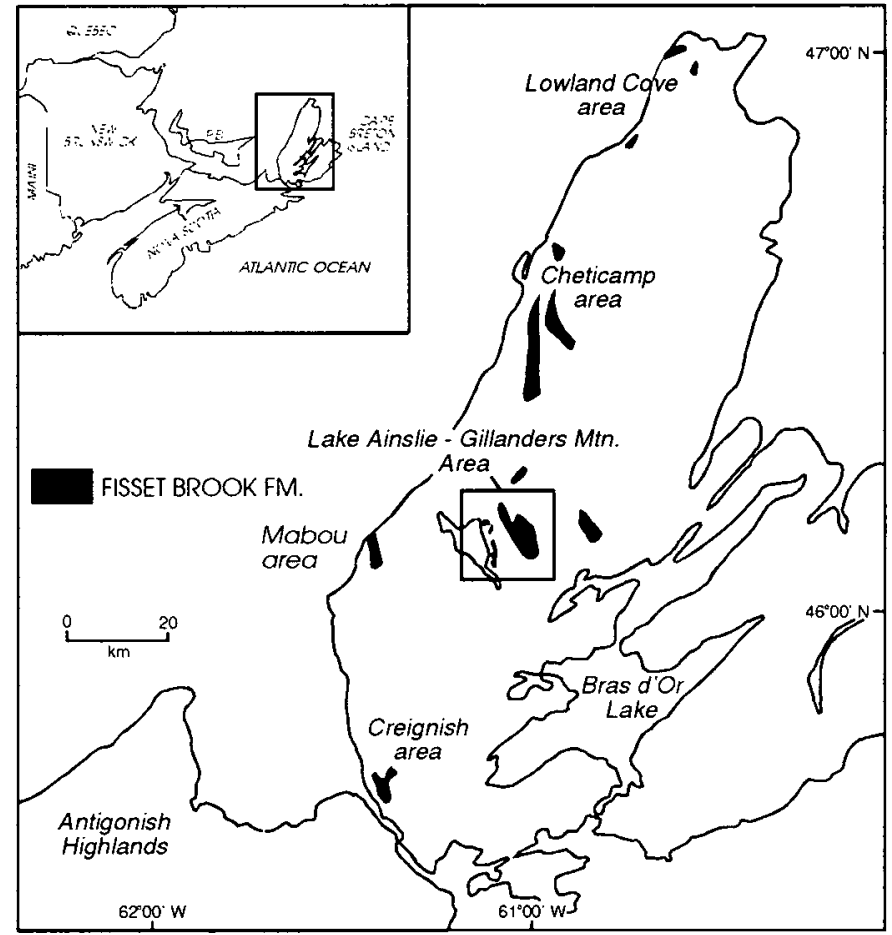

Fig. 1. Distribution of the Fisset Brook Formation and possibly correlative units in Cape Breton Island.

bonate rocks of the Windsor Group. A distinctive feature of the inliers is the occurrence of several groups of large, faultcontrolled barite-fluorite veins located within or immediately adjacent to rocks of the Fisset Brook Formation (Creed, 1968; Zurowski, 1972).

Farther to the east in the Gillanders Mountain area, distribution of the formation appears to be less fault-controlled, and the formation occupies a broad fold structure, partly faulted against a crystalline basement of igneous and metamorphic rocks (Fig. 2). This structure closes to the south where it is surrounded by clastic rocks of the Horton Group. With the exception of the Cooper Brook section, the Gillanders Mountain area had not previously been mapped in detail nor sampled for petrological studies. However, a network of new logging roads has improved access and increased exposure in the area, permitting more detailed mapping (Arnott 1994) than previously possible.

As shown in Figure 2, the distribution of the Fisset Brook Formation in both the Lake Ainslie and Gillanders Mountain areas has been substantially modified from the interpretations of previous workers (e.g., Kelly and Mackasey, 1965; French, 1985; Lynch et al., 1993b). In both areas, the formation is subdivided into three units on the basis of lithology, similar to the three-fold division in the type area in Fisset Brook: a sedimentary unit, a unit of mainly basaltic flows, and a unit of mainly rhyolitic flows (Fig. 2). Previously unrecognized gabbroic plutons are associated with the formation in the Gillanders Mountain area.

The Fisset Brook Formation unconformably overlies or is in faulted contact with varied plutonic and metamorphic rocks in both the Lake Ainslie and Gillanders Mountain areas (Huard, 1984; French, 1985; Barr et al., 1992). Only 


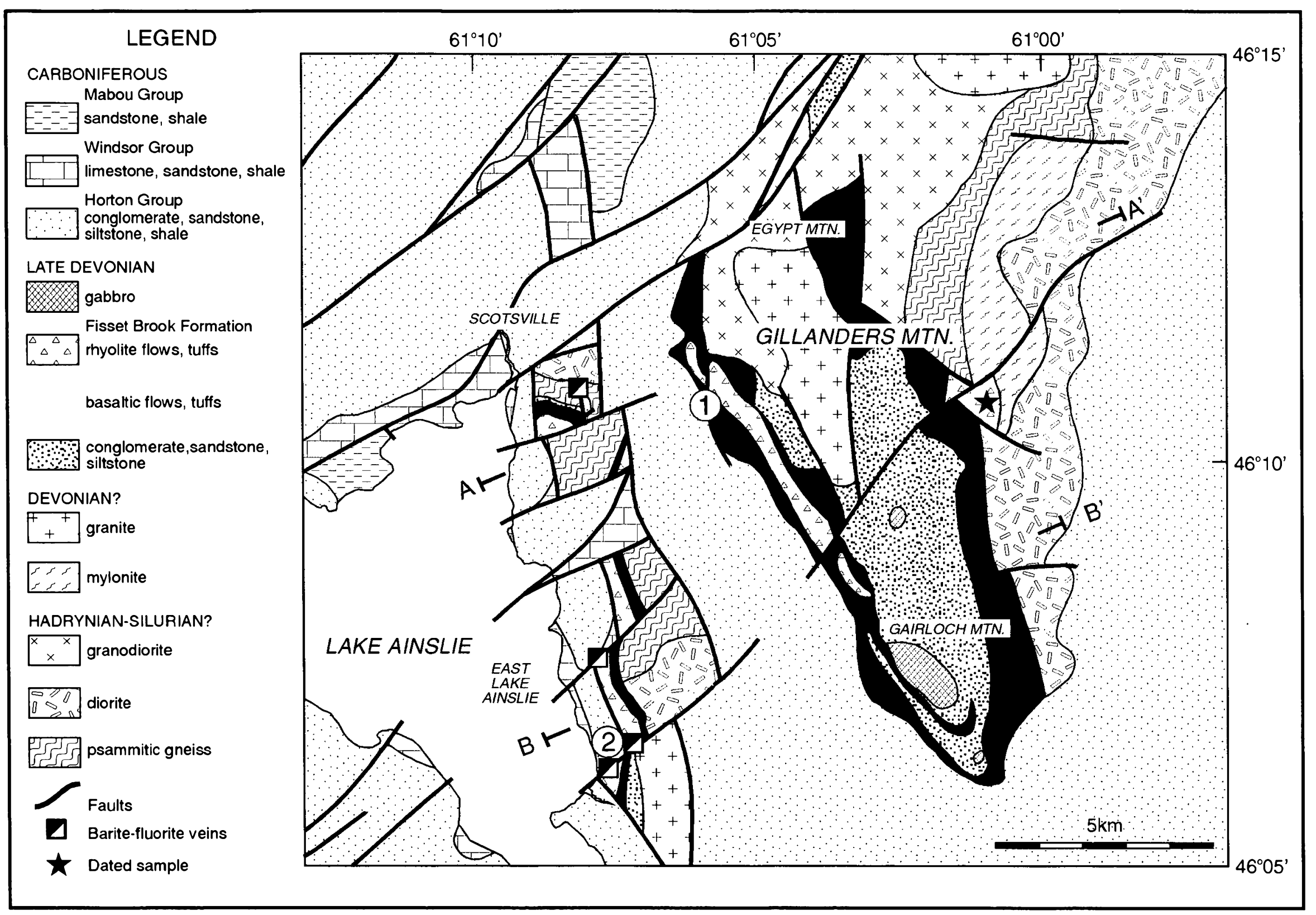

Fig. 2. Geological map, Lake Ainslie - Gillanders Mountain area. Star indicates the location of the dated sample Gil93-20, location\# 1 marks the Cooper Brook section, and location \#2 marks the Johnson Brook section. A-A' and B-B' indicate locations of cross-sections shown in Figure 3. Some details of the geology outside the Fisset Brook Formation are taken from Giles et al. (1995. 
in the Scotsville inlier is the unconformity exposed. Elsewhere, unconformable contacts are inferred from the presence of conglomerate in the basal unit of the Fisset Brook Formation (see description below), and from the overall map pattern (Fig. 2). On the eastern margin of the Gillanders Mountain area, basalt and rhyolite of the Fisset Brook Formation are in faulted contact with dioritic rocks.

Sedimentary rocks of the Horton Group are interpreted to overlie the Fisset Brook Formation. However, distinction between the sedimentary components of the two units is not always clear because of lithological similarities. Kelly and Mackasey (1965) formally placed the top of the Fisset Brook Formation at the top of the uppermost volcanic unit, and this definition was followed during the present study.

\section{Subdivisions of the Fisset Brook Formation}

\section{Sedimentary unit}

The lowermost unit of the Fisset Brook Formation consists of buff to brown polymictic conglomerate, red, grey, and green micaceous siltstone, and arkosic sandstone. These rocks form the core of what appears to be an anticlinal structure in the Gillanders Mountain area and overlie granitoid and metamorphic rocks in the Scotsville and East Lake Ainslie inliers. These sedimentary rocks appear to have a gradational relationship with the overlying basaltic unit, based on their distribution in the Gillanders Mountain area.

The basal conglomerate is comprised of brown, polymictic, subangular pebble conglomerate grading upward into roundstone cobble conglomerate with clasts up to $20 \mathrm{~cm}$ in size. The clasts consist of psammitic gneiss, diorite, granitoids, and a variety of mafic to felsic metavolcanic(?) rocks.

The bulk of the unit is made up of buff-coloured pebble paraconglomerate and micaceous red-brown siltstone to fine grained arkosic sandstone. The pebble paraconglomerate is arkosic with clasts mainly of vein quartz and granitoid rocks in a groundmass of fine grained quartz and feldspar, sericite, and clay. Clasts in the conglomerate are rounded to subrounded and range in diameter from $1 \mathrm{~mm}$ to $4 \mathrm{~cm}$. The quartz grains in siltstone/sandstone are mainly angular. Shale occurs rarely in this unit. The red-brown siltstone appears to occur mainly in the upper part of the unit where it was observed in contact with basalt and intermixed with basalt in peperitic structures.

\section{Basaltic unit}

The basaltic unit consists of a series of flows and minor interlayered vitric and lapilli tuff. Flow tops (and to a lesser extent, bottoms) are characterized by abundant vesicles and/ or amygdales up to $1 \mathrm{~cm}$ in diameter. The amygdales are filled with chlorite, hematite, calcite, or quartz. In some outcrops, the vesicles and amygdales are elongate, presumably in the direction of flow. The interior parts of flows are massive and range in colour from black to maroon. In the northern part of the map area and in Cooper Brook, several (at least 3) flows can be recognized on the basis of alternat- ing amygdaloidal flow tops and massive flow interiors. Maximum flow thickness was not determinable, but in some places, flows are as thin as about $2 \mathrm{~m}$.

The basalt is locally mixed with red-brown micaceous siltstone in peperitic structures, indicative of extrusion onto wet, unconsolidated sediments perhaps in a shallow lacustrine environment. In the Lake Ainslie area, the only place where such peperitic structures were observed was in drill core from the Bald Hill barite-fluorite occurrences in the East Lake Ainslie inlier.

The basalt flows are mainly fine grained and ophitic to intergranular in texture. Their primary mineralogy is dominated by plagioclase and clinopyroxene, the latter of augitic composition. Plagioclase composition ranges from $A n_{50}$ to $A n_{70}$, with rims and patches of secondary albite. Evidence for the former presence of olivine in the form of pseudomorphs with characteristic shape and curved fractures shows that it was a major mineral in these rocks before it was altered to a mixture of minerals including serpentine, chlorite and pumpellyite. Chlorite, titanite, epidote and hematite are also abundant secondary minerals. More detailed petrographic descriptions and representative mineral analyses are given in Arnott (1994).

\section{Rhyolitic unit}

The rhyolitic unit is comprised of both flows and tuffs. It is best exposed along Cooper Brook in the Gillanders Mountain area, where rhyolite forms cliffs as high as $100 \mathrm{~m}$, and in Johnson Brook in the East Lake Ainslie inlier (Fig. 2). In the Gillanders Mountain area, the rhyolite unit occurs within the basaltic unit and is discontinuous along strike whereas in the East Lake Ainslie area it occurs above the basaltic unit and appears to have been essentially continuous (prior to faulting).

The rhyolite varies in colour from pink to orange and is commonly porphyritic. Most common is sinuously flow-banded rhyolite, some of which has been interpreted (from the presence of fiamme and lapilli) as welded ash flows and fine grained, accretionary lapilli tuffs (Creed, 1968; Huard, 1984). Associated more massive tuffs are mainly lithic lapilli tuffs or more rarely feldspar crystal-lithic tuffs. Most contain vugs lined with euhedral smoky quartz, and are more-or-less devitrified. The rhyolite is composed of quartz and orthoclase, with minor albite, chloritized biotite, and magnetite. It is variably porphyritic, with embayed quartz more common than orthoclase; groundmass textures vary from eutaxitic to granophyric, with a widespread, spherulitic textural overprint.

Botryoidal structures, $<1$ to $50 \mathrm{~cm}$ in size, with associated brecciated matrix, are developed locally in the rhyolite in both Cooper Brook and Johnson Brook. These are of enigmatic origin but were interpreted by French (1985) as pillow-like structures indicative of extrusion into an aqueous environment.

Adjacent to the large barite-fluorite veins in the Lake Ainslie area, the rhyolite does not show any distinctive wallrock alteration, although numerous small fracture-controlled 
veinlets of purple fluorite and less common pink barite are found in the general vicinity. The only intensely altered rhyolite occurs at the north end of the East Lake Ainslie inlier, where the rhyolite unit is faulted against limestone of the Windsor Group; here the rhyolite is pale grey in colour, pervasively leached and porous, with manganiferous(?) coatings and infillings.

\section{Gabbro}

At least three gabbroic plutons and a gabbroic dyke occur in the sedimentary unit in the Gillanders Mountain area and may represent feeders to the overlying basalts. In the two southern plutons, the gabbro tends to become finer grained toward the margins and hence appears to be chilled against the sedimentary rocks, although the latter generally do not show evidence of contact metamorphism, except at one locality in the south.

The gabbro varies from fine grained and subophitic to coarse grained and ophitic. It consists mainly of plagioclase and clinopyroxene (augite), with rare relict olivine and more common pseudomorphs after olivine. Plagioclase and clinopyroxene compositions are similar to those in the basaltic samples. Secondary minerals in the groundmass include pumpellyite, chlorite, epidote, and titanite. Former olivine phenocrysts have been replaced by the same secondary minerals as in the basaltic unit. Small amounts of olivine remain unaltered in two of these samples. The plagioclase is partly replaced by sericite and clay minerals and has also undergone some albitization.

\section{STRUCTURAL FEATURES}

A marked structural contrast between the Lake Ainslie and Gillanders Mountain areas is readily apparent from Figure 2.

In the Lake Ainslie area, the dominant structure is a north-south array of rhombic fault blocks, with Devonian and older rocks exposed in uplifted horst blocks in the East Lake Ainslie and Scotsville inliers. Within these horsts, the rocks of the Fisset Brook Formation dip steeply to the west and south-west off the older crystalline infrastructure (Figs. $3,4 a)$, and may represent the westward-facing limb of a syncline disrupted by faulting. Carboniferous rocks of the Horton and Windsor groups are folded and down-faulted against these horsts; the folds, which are overturned along the western side of the blocks, generally plunge south at about $10^{\circ}$ (Fig. 4b).

In the Gillanders Mountain area, the dominant structure appears to be a large-scale anticlinal fold closing toward the south, cored largely by rocks of the Fisset Brook Formation. Toward the north and along the eastern flank of the anticline, the crystalline infrastructure to the formation is exposed on the upthrown sides of a series of cross-cutting faults. The eastern limb of the anticline is not well exposed so the geometry of the fold structure is not well constrained; however, the available bedding data suggest that the anticline may plunge toward the southwest (Fig. 4c), which would be possible if the eastern limb dips steeply to the west (i.e., is overturned). Along the western and southern margins of the anticline, folds in the Horton Group plunge gently to-

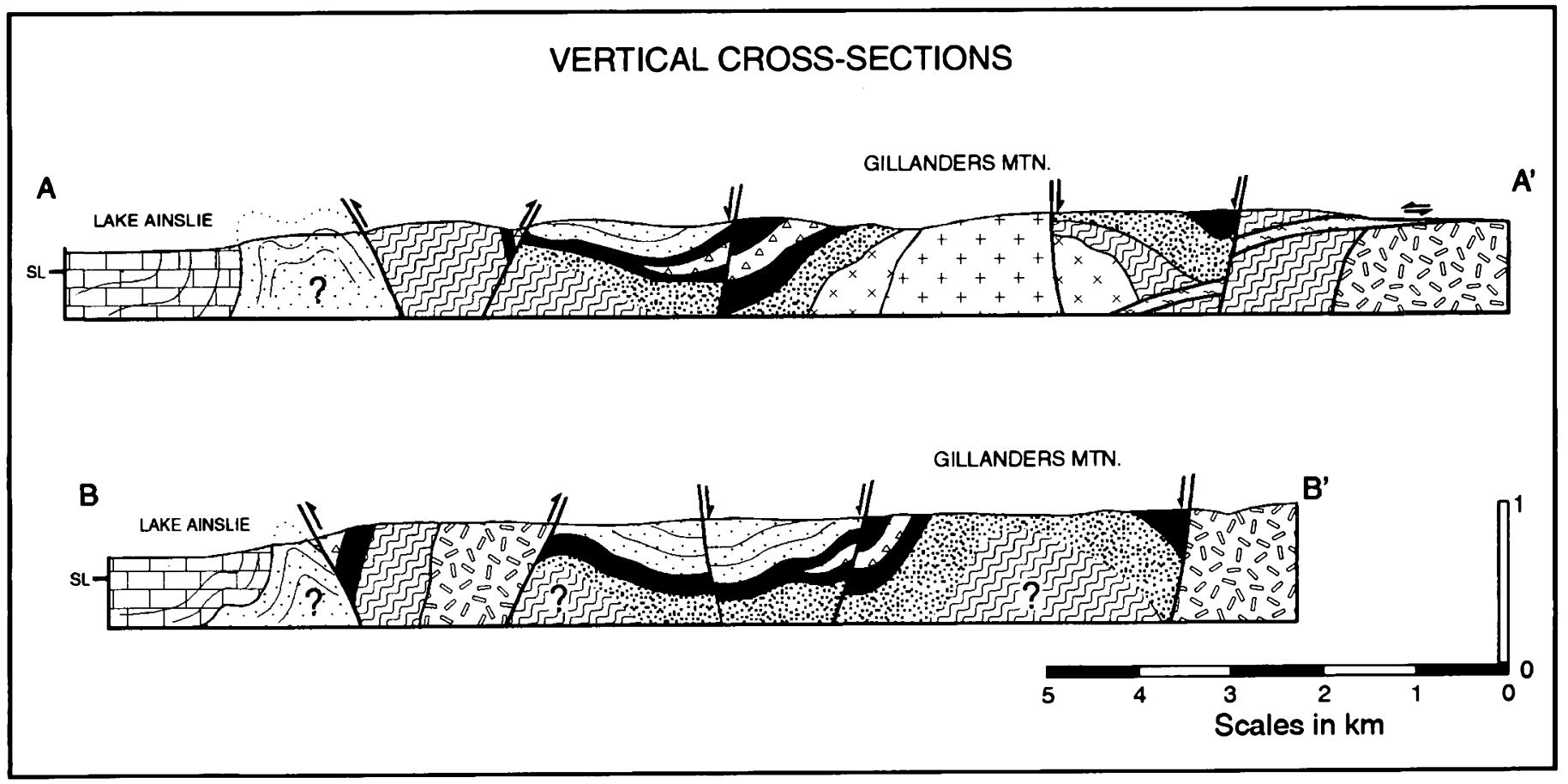

Fig. 3. Cross-sections $A-A^{\prime}$ and $B-B^{\prime}$ (locations indicated on Figure 2) to illustrate the contrast in inferred structural relationships in the Lake Ainslie and Gillanders Mountain areas. Legend as in Figure 2. 
LAKE AINSLIE (FISSET BK)

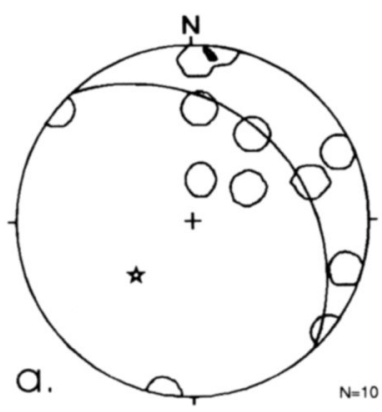

LAKE AINSLIE (HORTON-WINDSOR)

N

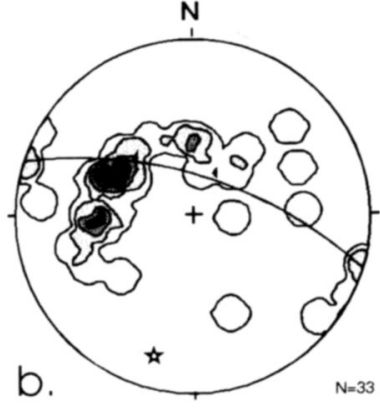

GILLANDERS MTN (FISSET BK)

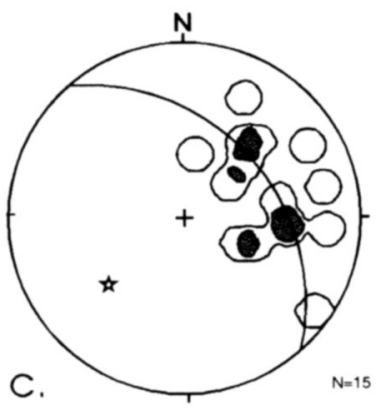

GILLANDERS MTN (HORTON)

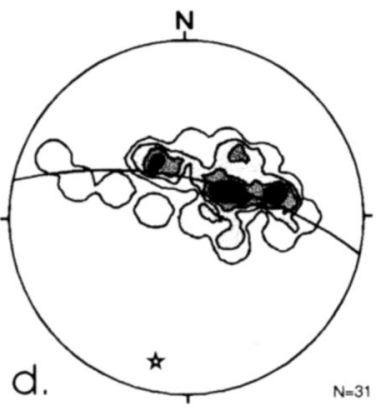

Fig. 4. Contoured stereoplots of poles to bedding and inferred mean fold axes (star symbol) in the Fisset Brook Formation (4a and $4 c$ ), and in the Horton and Windsor groups ( $4 b$ and $4 d$ ).

ward the south (Fig. 4d). On the eastern side of the anticline, rocks of the Horton Group are not obviously folded and dip more-or-less uniformly to the west-northwest.

Essentially the same directions of faulting can be recognized in both the Lake Ainslie and Gillanders Mountain areas: (i) east-northeast- to northeast-trending dextral oblique-slip faults, (ii) north- to north-northwest-trending dipslip faults, and (iii) southeast-trending sinistral(?) strikeslip faults. Although the east-northeast- to northeast-trending faults commonly offset the other fault sets, there is evidence from Lake Ainslie that there were synchronous movements on all three sets during the development of the array of rhombic fault blocks there (Macdonald, 1994).

The contrast in structural styles between such closely adjacent areas can be explained if the broadly folded Gillanders Mountain area acted as a north-south structural buttress during regional, northeast, dextral strike-slip faulting in the Late Carboniferous-Early Permian (e.g., Bradley, 1982, 1983; McCutcheon and Robinson, 1987). Against this buttress, the Lake Ainslie array of blocks could have been pushed up to further expose the Fisset Brook Formation and its infrastructure. During such a process, pre-existing faults such as the north- to north-northwest-trending dip-slip faults would probably have been re-activated.

\section{Chemical characteristics}

\section{OF THE IGNEOUS ROCKS}

The following petrochemical interpretation is based on analyses of 8 samples from the Lake Ainslie area and 33 samples from the Gillanders Mountain area, obtained as part of the present study, combined with an additional 8 analyses from the Gillanders Mountain area taken from French (1985) and Huard (1984), and 11 analyses from the Lake Ainslie area taken from Huard (1984). The data are tabulated in Arnott (1994), French (1985), and Huard (1984), except for the 8 analyses from the Lake Ainslie area which are presented here (Table 1). In addition, data for 4 representative samples from the Gillanders Mountain area which were analyzed for rare-earth elements as part of the present study are listed in Table 2. Chemical data from Blanchard (1982) and Blanchard et al. (1984) are not included in this compilation because of differences in the assemblage of elements analyzed.

The analyzed samples are clearly bimodal with respect to their $\mathrm{SiO}_{2}$ contents and display a range (volatile-free) from $45 \%$ to $58.5 \%$ in the mafic rocks and $73 \%$ to $84 \%$ in the rhyolites (Fig. 5). The highest silica rhyolites may have been secondarily silicified because their silica contents are outside the range typical of igneous rocks (e.g., Wilson, 1989); however, petrographic evidence for silicification is difficult to assess due to their cryptocrystalline texture. Alkali element mobility is suggested by a wide range in $\mathrm{K}_{2} \mathrm{O}$ (Fig. 5a) and $\mathrm{Na}_{2} \mathrm{O}$ (not shown), and also by the "igneous spectrum" diagram of Hughes (1973), on which few volcanic samples plot in the igneous field (Fig. 6). The rhyolitic samples show anomalously high potash values (Fig. 5a), and $\mathrm{K} / \mathrm{Na}$ ratios (Fig. 6). In comparison to the basaltic and rhyolitic samples, gabbroic samples appear less altered in that they generally show less chemical variation.

Trace elements show wide variation and little correlation with silica (Arnott, 1994), including elements which are normally considered to be relatively "immobile" (such as $\mathrm{Y}, \mathrm{Nb}$, and $\mathrm{Zr}$; Winchester and Floyd, 1976, 1977). However, these elements show reasonable linear correlation in the mafic samples (e.g., Fig. 7a, b), which suggests that their ratios may not have been strongly affected by alteration and may still be useful as petrochemical indicators. On this basis, a plot of $\mathrm{Zr} / \mathrm{TiO}_{2}$ versus silica indicates that the mafic samples are subalkalic (Fig. 7c), an interpretation supported by low concentrations of $\mathrm{Nb}$ (Fig. 8). In contrast, the similarity of the average alkali element concentrations to the average alkalic basalt (Fig. 8) is interpreted to reflect secondary enrichment in the alkali elements. The Lake Ainslie basalts are especially enriched in these elements, perhaps related to the hydrothermal activity which formed barite-fluorite deposits in the area (Creed, 1968; Huard, 1984; Macdonald, 1994 and unpublished data).

The felsic samples from the Lake Ainslie area tend to have higher $\mathrm{Zr} / \mathrm{TiO}_{2}$ values than those from the Gillanders Mountain area (Fig. 7c). Their $\mathrm{Ga} / \mathrm{Al}$ ratios (2.5 to 3.5) suggest that they are transitional to A-type granites (average $\mathrm{Ga} / \mathrm{Al}$ = 3.75; Whalen et al., 1987), but average $Z r$ and $Y$ contents (181 ppm and $54 \mathrm{ppm}$, respectively) in analyzed rhyolites from both the Lake Ainslie and Gillanders Mountain areas are much lower than in the average A-type granite $(\mathrm{Zr}=$ $528 \mathrm{ppm}$ and $\mathrm{Y}=75 \mathrm{ppm}$; Whalen et al., 1987).

Chondrite-normalized, rare-earth element (REE) data 
Table 1. Major and trace element analyses* (in weight \% and ppm, respectively) for samples from the Lake Ainslie area.

\begin{tabular}{|c|c|c|c|c|c|c|c|c|}
\hline & AM17 & AM28 & AM31 & AM50 & AM14 & AM16 & AM32 & AM49 \\
\hline $\mathrm{SiO}_{2}$ & 75.62 & 76.05 & 75.49 & 75.85 & 46.55 & 46.66 & 47.31 & 46.46 \\
\hline $\mathrm{TiO}_{2}$ & 0.11 & 0.09 & 0.08 & 0.09 & 2.55 & 2.26 & 2.13 & 1.99 \\
\hline $\mathrm{Al}_{2} \mathrm{O}_{3}$ & 11.64 & 11.28 & 11.77 & 11.69 & 16.66 & 15.71 & 14.90 & 17.51 \\
\hline $\mathrm{Fe}_{2} \mathrm{O}_{3}{ }^{\mathrm{t}}$ & 1.91 & 1.27 & 1.84 & 0.88 & 11.91 & 11.44 & 14.28 & 9.98 \\
\hline $\mathrm{MnO}$ & 0.01 & 0.01 & 0.02 & 0.01 & 0.28 & 0.59 & 0.24 & 0.59 \\
\hline $\mathrm{MgO}$ & nd & nd & nd & 0.04 & 5.05 & 6.29 & 5.72 & 6.23 \\
\hline $\mathrm{CaO}$ & 0.06 & 0.06 & 0.04 & 0.07 & 8.42 & 6.34 & 5.55 & 8.37 \\
\hline $\mathrm{Na}_{2} \mathrm{O}$ & 1.12 & 0.82 & 0.70 & 0.94 & 3.77 & 2.11 & 4.32 & 2.90 \\
\hline $\mathrm{K}_{2} \mathrm{O}$ & 8.91 & 8.94 & 9.79 & 8.98 & 0.63 & 3.96 & 2.24 & 0.83 \\
\hline $\mathrm{P}_{2} \mathrm{O}_{5}$ & 0.01 & 0.02 & 0.01 & 0.01 & 0.37 & 0.34 & 0.32 & 0.30 \\
\hline LOI & 0.50 & 0.50 & 0.40 & 0.80 & 4.20 & 3.60 & 3.50 & 4.10 \\
\hline Total & 99.90 & 99.05 & 100.14 & 99.36 & 100.39 & 99.30 & 100.51 & 99.26 \\
\hline $\mathrm{Ba}$ & 265 & 387 & 367 & 384 & 432 & 1553 & 1553 & 281 \\
\hline $\mathrm{Rb}$ & 346 & 413 & 418 & 429 & 6 & 99 & 194 & 21 \\
\hline $\mathrm{Sr}$ & 14 & 18 & 18 & 20 & 502 & 1854 & 397 & 320 \\
\hline $\mathrm{Y}$ & 47 & 59 & 52 & 62 & 37 & 38 & 38 & 35 \\
\hline $\mathrm{Zr}$ & 249 & 158 & 148 & 153 & 210 & 257 & 195 & 172 \\
\hline $\mathrm{Nb}$ & 29 & 43 & 47 & 42 & 8 & 7 & 7 & 8 \\
\hline Th & 23 & 25 & 38 & 31 & 10 & 10 & 10 & 10 \\
\hline $\mathrm{Pb}$ & 17 & 21 & 12 & 61 & 10 & 29 & 28 & 10 \\
\hline $\mathrm{Ga}$ & 20 & 18 & 23 & 20 & 19 & 17 & 16 & 19 \\
\hline $\mathrm{Zn}$ & 13 & 24 & 13 & 26 & 117 & 2226 & 161 & 556 \\
\hline $\mathrm{Cu}$ & 5 & 5 & 5 & 19 & 30 & 12 & 25 & 50 \\
\hline $\mathrm{Ni}$ & 5 & 5 & 5 & 5 & 56 & 60 & 56 & 85 \\
\hline V & 11 & 12 & 5 & 12 & 260 & 265 & 265 & 251 \\
\hline $\mathrm{Cr}$ & 7 & 12 & 12 & 5 & 17 & 44 & 54 & 57 \\
\hline
\end{tabular}

\footnotetext{
*Analyses done by standard X-ray fluorescence techniques at the Nova Scotia Regional Geochemical Centre, Saint Mary's University, Halifax. nd = not detected, LOI = loss on ignition (\% weight loss after heating for $1.5 \mathrm{hrs}$ at $\left.1050^{\circ} \mathrm{C}\right)$.
}

for four samples from the Gillanders Mountain area (Fig. 9) show only slight enrichment in the light REE relative to the heavy REE. The basalt and gabbro samples display small Eu anomalies, whereas the rhyolite sample shows a much larger anomaly. In the mafic samples, these data suggest that plagioclase fractionation may have played only a minor role in magma evolution. However, in the rhyolite sample, either feldspar fractionation was more significant or residual feldspar remained in the source rock during the melting process. Previous REE data reported by Huard (1984) and French (1985) were not used in this study because of uncertainty in the comparability of the analyses. However, in general, the data show patterns similar to those reported here, although they are more erratic, perhaps in part due to alteration (Huard, 1984).

The REE patterns of the mafic rocks are very similar to those typical of within-plate tholeiitic basalts, for example, that of a tholeiitic basalt from the Snake River continental flood basalt province (Fig. 9). Such patterns are generally interpreted to indicate melts derived from the subcontinental upper mantle. The rhyolite sample is unusual in that it shows very low total REE abundance, less than that in the mafic samples (Fig. 9). Total REE contents reported by Huard (1984) for rhyolites from the Lake Ainslie area are similarly low. Typically, rhyolite contains elevated REE contents compared to mafic rocks, as illustrated by a rhyolite from the Kenya Rift (Fig. 9). The low REE abundances in rhyolite samples from the Lake Ainslie and Gillanders Mountain areas may indicate that the magmas were highly fractionated, or that they were derived from crustal sources with a high content of residual refractory minerals with a high REE content, such as zircon (e.g., Hanson, 1980). The latter interpretation is consistent with the low $\mathrm{Zr}$ and $\mathrm{Y}$ contents in the rhyolite samples compared to other within-plate felsic magmas such as A-type granites.

On the $\mathrm{Nb}-\mathrm{Zr}-\mathrm{Y}$ diagram for mafic rocks (Fig. 10), both basaltic and gabbroic samples plot mainly in the "withinplate tholeiite/volcanic arc" field. From other diagrams (e.g., 
Table 2. Major (in weight \%), trace (in ppm), and rare-earth (in ppm) element analyses for selected samples from the Gillanders Mountain area.

\begin{tabular}{|c|c|c|c|c|}
\hline & Gil212 & Gills & Gil09 & Gil20 \\
\hline $\mathrm{SiO}_{2}$ & 53.02 & 50.19 & 47.06 & 74.74 \\
\hline $\mathrm{TiO}_{2}$ & 2.14 & 1.63 & 2.67 & 0.22 \\
\hline $\mathrm{Al}_{2} \mathrm{O}_{3}$ & 13.94 & 15.97 & 13.52 & 12.15 \\
\hline $\mathrm{Fe}_{2} \mathrm{O}_{3}$ & 12.45 & 11.08 & 13.46 & 1.10 \\
\hline $\mathrm{MnO}$ & 0.31 & 0.16 & 0.21 & 0.01 \\
\hline $\mathrm{MgO}$ & 3.25 & 5.68 & 5.43 & nd \\
\hline $\mathrm{CaO}$ & 4.30 & 8.17 & 8.20 & nd \\
\hline $\mathrm{Na}_{2} \mathrm{O}$ & 5.60 & 2.54 & 3.61 & 0.84 \\
\hline $\mathrm{K}_{2} \mathrm{O}$ & 1.79 & 1.27 & 0.93 & 8.91 \\
\hline $\mathrm{P}_{2} \mathrm{O}_{5}$ & 0.61 & 0.20 & 0.62 & 0.05 \\
\hline L.O.I. & 2.40 & 2.40 & 3.10 & 0.90 \\
\hline Total & 99.81 & 99.29 & 98.81 & 98.92 \\
\hline $\mathrm{Ba}$ & 500 & 165 & 346 & 683 \\
\hline $\mathrm{Rb}$ & 67 & 33 & 13 & 318 \\
\hline $\mathrm{Sr}$ & 132 & 227 & 356 & 33 \\
\hline$Y$ & 57 & 40 & 64 & 25 \\
\hline $\mathrm{Zr}$ & 316 & 137 & 243 & 144 \\
\hline $\mathrm{Nb}$ & 19 & 8 & 12 & 15 \\
\hline Th & 4.84 & 4.28 & 1.77 & 27.71 \\
\hline $\mathrm{Cu}$ & 21 & 69 & 75 & 5 \\
\hline $\mathrm{Pb}$ & 13 & 10 & 10 & 10 \\
\hline $\mathrm{Zn}$ & 761 & 83 & 110 & 6 \\
\hline $\mathrm{Ni}$ & 22 & 77 & 32 & 5 \\
\hline $\mathrm{Cr}$ & 8 & 44 & 128 & 5 \\
\hline V & 283 & 213 & 283 & 7 \\
\hline $\mathrm{Ga}$ & 20 & 21 & 15 & 13 \\
\hline $\mathrm{La}$ & 36.27 & 10.69 & 21.44 & 10.67 \\
\hline $\mathrm{Ce}$ & 78.51 & 27.22 & 50.33 & 20.90 \\
\hline Pr & 10 & 3.74 & 7.14 & 2.80 \\
\hline $\mathrm{Nd}$ & 41.04 & 16.69 & 32.35 & 10.91 \\
\hline Sm & 8.69 & 4.97 & 7.91 & 2.75 \\
\hline $\mathrm{Eu}$ & 2.24 & 1.46 & 2.48 & 0.320 \\
\hline Gd & 9.63 & 5.62 & 9.57 & 2.64 \\
\hline Tb & 1.26 & 0.864 & 1.39 & 0.440 \\
\hline Dy & 8.82 & 5.96 & 9.42 & 3.38 \\
\hline Ho & 1.68 & 1.14 & 1.84 & 0.690 \\
\hline $\mathrm{Er}$ & 4.66 & 3.51 & 5.24 & 2.26 \\
\hline $\mathrm{Tm}$ & 0.654 & 0.522 & 0.760 & 0.360 \\
\hline $\mathrm{Yb}$ & 4.38 & 3.35 & 4.67 & 2.60 \\
\hline Lu & 0.688 & 0.500 & 0.770 & 0.380 \\
\hline $\mathrm{Hf}$ & 7.08 & 3.44 & 5.79 & 3.79 \\
\hline $\mathrm{Ta}$ & 0.844 & 0.643 & 0.630 & 1.33 \\
\hline
\end{tabular}

* Major and first group of trace element analyses by standard XRF fluorescence techniques at the Nova Scotia Regional Geochemical Centre, Saint Mary's University, Halifax. REE, Hf, and Ta analyses by ICP-MS at Memorial University of Newfoundland, St. John's. nd $=$ not detected, LOI $=$ loss on ignition $(\%$ weight loss after

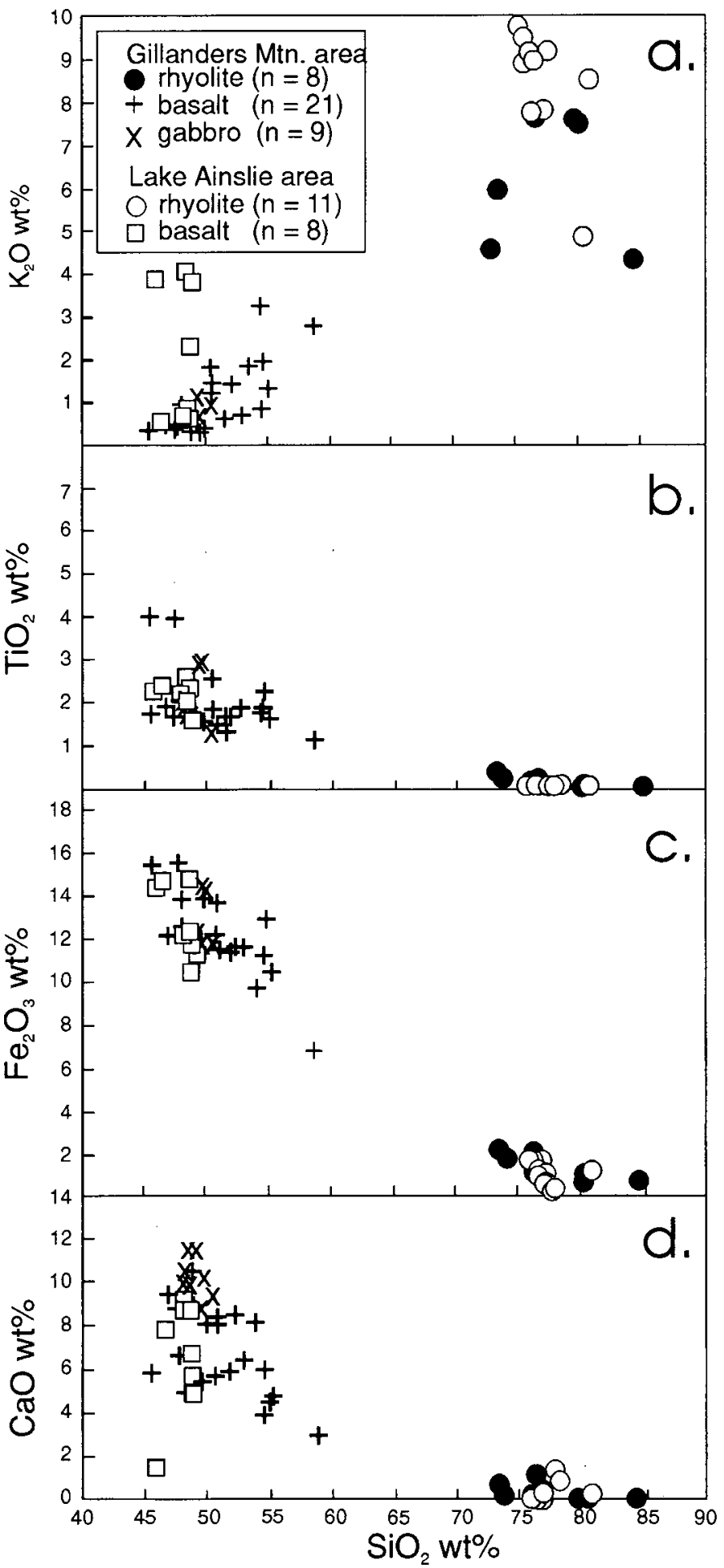

Fig. 5. Plots of (a) $\mathrm{K}_{2} \mathrm{O}$, (b) $\mathrm{TiO}_{2}$, (c) total $\mathrm{Fe}$ as $\mathrm{Fe}_{2} \mathrm{O}_{3}$, and (d) $\mathrm{CaO}$ against $\mathrm{SiO}_{2}$ (all in weight \%) to illustrate chemical variations in samples from the Lake Ainslie and Gillanders Mountain areas. Data sources are Table 1 and Arnott (1994), French (1985), and Huard (1984), as described in the text. Data have been calculated to total $100 \%$ volatile-free.

heating for 1.5 hours at $1050^{\circ} \mathrm{C}$ ). Sample types: Gil212, 15, basalt flows; 09 , gabbro; 20 , rhyolite. 


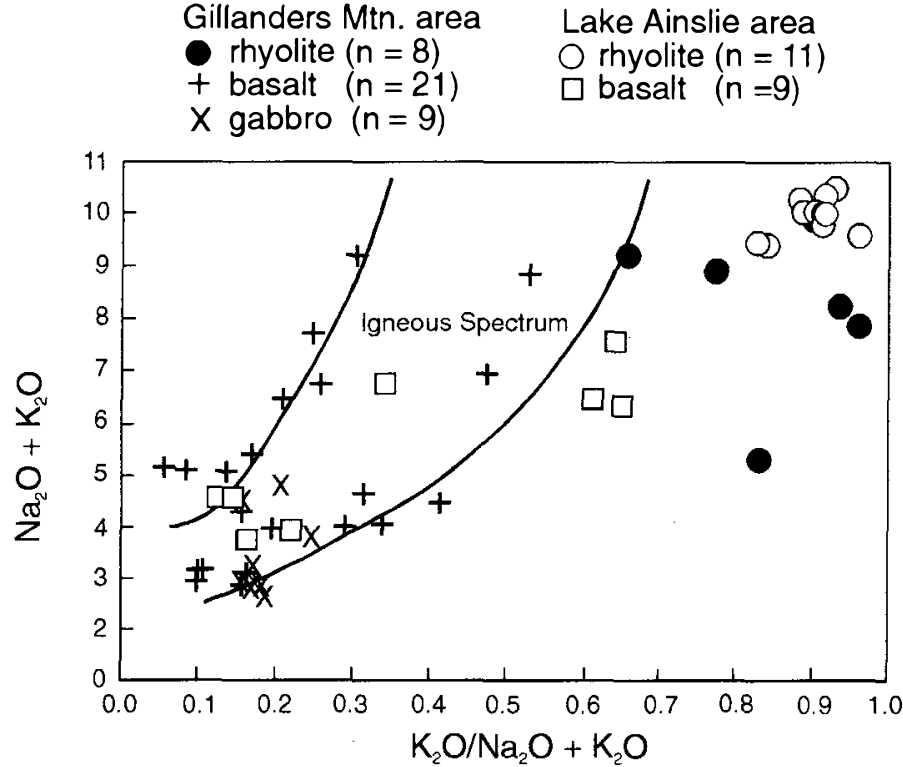

Fig. 6. Plot of $\mathrm{Na}_{2} \mathrm{O}+\mathrm{K}_{2} \mathrm{O}$ (weight \%) against $\mathrm{K}_{2} \mathrm{O} / \mathrm{Na}_{2} \mathrm{O}+\mathrm{K}_{2} \mathrm{O}$, with fields from Hughes (1973), to demonstrate the probable mobility of alkali elements in analysed samples from the Lake Ainslie and Gillanders Mountain areas. Data are as in Figure 5.

Fig. 7b), it seems likely these rocks are within-plate basalts and unlikely to be arc-related. The shift toward the arc field on Figure 10 can be attributed to elevated $Y$ values in the samples; high average $Y$ values compared to average withinplate suites are apparent on Figure 8. This enrichment in $Y$ may reflect an abundance of $Y$ in the source rocks for the mafic magma, in contrast to the apparent $Y$ depletion in the source of the rhyolites. An $\mathrm{Rb} / \mathrm{Y}+\mathrm{Nb}$ diagram (Fig. 11) indicates that the rhyolites formed in a within-plate tectonic setting, consistent with the within-plate characteristics of the associated mafic rocks.

The chemical similarity between the basalts and gabbros in the Gillanders Mountain area, including their nearparallel REE trends (Fig. 9), indicate that they are closely related, and supports the interpretation that the gabbros are the intrusive equivalents of the basaltic rocks.

\section{GeOCHRONOLOGY}

Previous interpretations of the age of the Fisset Brook Formation, based on fossils and on dating by the Rb-Sr method, produced varied results. Cormier and Kelley (1964) reported $\mathrm{Rb}$-Sr ages of $349 \pm 15 \mathrm{Ma}$ for volcanic samples from the type section in Fisset Brook, and $348 \pm 20 \mathrm{Ma}$ for volcanic samples from the Lake Ainslie area. These numbers appear consistent with the Early Mississippian age suggested by Kelley and Mackasey (1965), based on spores and plant fragments in the basal sedimentary unit of the type section. However, recalculation of the $\mathrm{Rb}-\mathrm{Sr}$ ages using the currently accepted decay constant by Keppie and Smith (1978) gave $376 \pm 12$ $\mathrm{Ma}$ and $370 \pm 20 \mathrm{Ma}$, which do not agree as well with the inferred palaeontologic age. Huard (1984) subsequently reported a Rb-Sr isochron age of $344.4 \pm 6.6 \mathrm{Ma}$ for sixteen volcanic samples from the Lake Ainslie area, including data
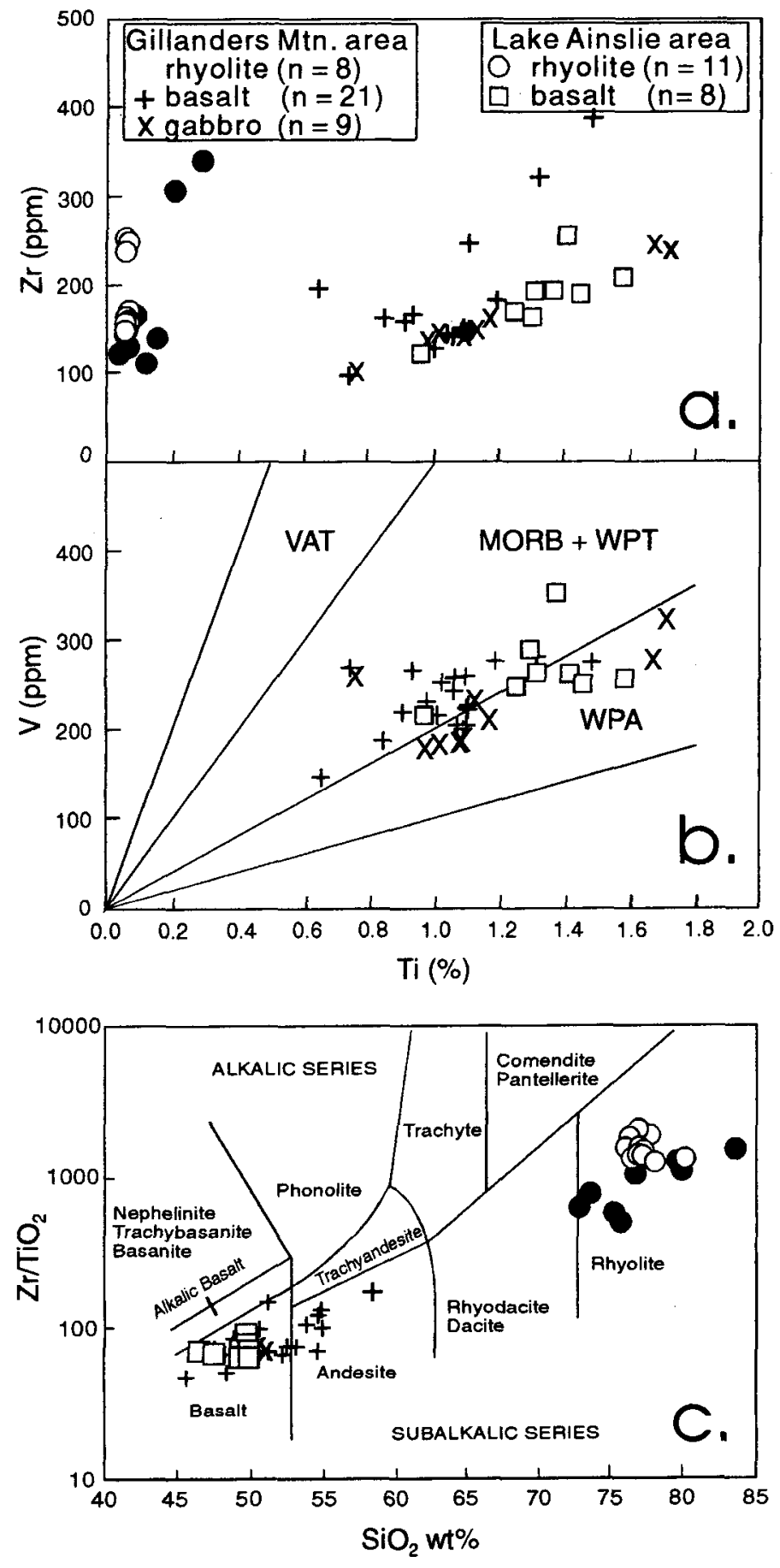

Fig. 7. Plots of (a) $\mathrm{Zr}$ against $\mathrm{Ti}$, (b) $\mathrm{Zr}$ against $\mathrm{Ti}$ (mafic samples only), and (c) $\mathrm{Zr} / \mathrm{TiO}_{2}$ against $\mathrm{SiO}_{2}$. Fields in (b) are from Shervais (1982) and in (c) are from Winchester and Floyd (1977).

from re-analysis of the original 5 samples of Cormier and Kelley (1964) and an additional 11 samples from his own study. Re-analysis of samples from the type section gave a similar age (R.F. Cormier, unpublished data cited by Huard, 1984). Blanchard et al. (1984) reported the presence of Late Devonian plant fossils in the eastern belt of the Fisset Brook Formation in the Cheticamp area, and on this basis suggested that the formation in that area might be older than in the type section.

Because of the uncertainty in age, a sample for $\mathrm{U}-\mathrm{Pb}$ 


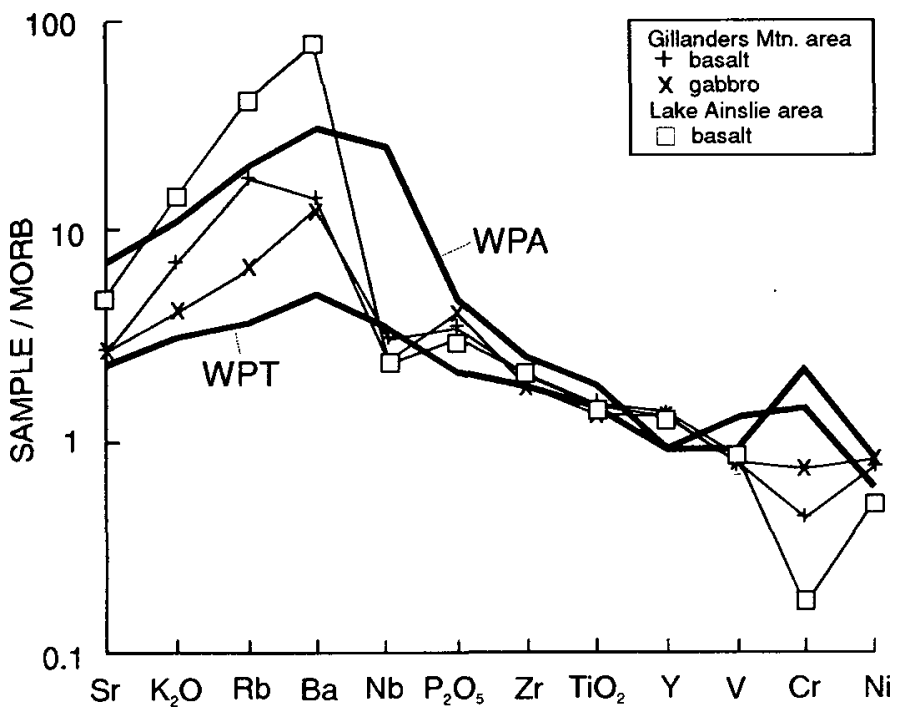

Fig. 8. Multi-element variation diagram to illustrate chemical similarity of average basaltic and gabbroic rocks from the study area to the average within-plate tholeiite from Pearce (1982). Data are normalized to average mid-ocean ridge basalt from Pearce (1982), except V value estimated from Shervais (1982). Grey lines are average within-plate tholeiitic (WPT) and average withinplate alkalic basalt (WPA) from Pearce (1982).

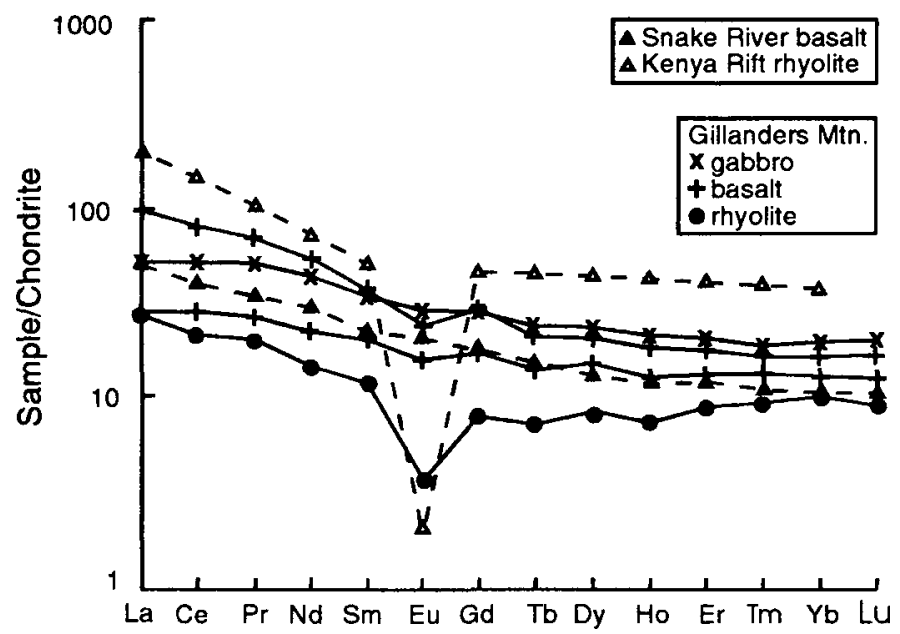

Fig. 9. Plots of chondrite-normalized REE data for basalt, gabbro, and rhyolite samples from the Gillanders Mountain area (data from Table 2), compared to a tholeiitic basalt from the Snake River Plain (Wilson, 1989, p. 300) and a rhyolite from the Naivasha volcanic field in the Kenya Rift (Wilson, 1989, p. 348). Chondrite-normalizing values are from Haskin et al. (1968).

dating was collected from a rhyolite flow near Gillanders Mountain (Fig. 2). The dated sample is pink to brown, with alternating layers of spherulitic and microgranular quartz and $\mathrm{K}$-feldspar, and containing scattered microphenocrysts of the same two minerals. No identifiable mafic mineral other than iron oxide is present.

Four zircon fractions were analyzed (Table 3; Fig. 12). All exhibit slight $\mathrm{Pb}$ loss; a regression line through all four fractions indicates an age of $373 \pm 4 \mathrm{Ma}$. We interpret this age to represent the time of crystallization of rhyolite in the upper part of the Fisset Brook Formation. Using the time-

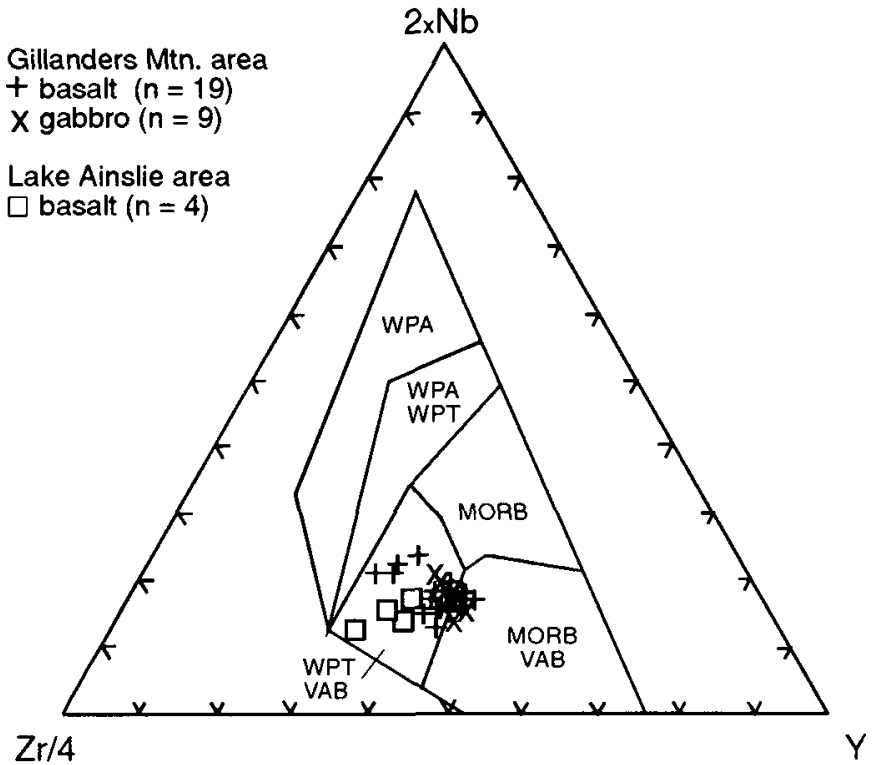

Fig. 10. Tectonic setting discrimination diagram for mafic samples from the Lake Ainslie and Gillanders Mountain areas, with fields from Meschede (1986).

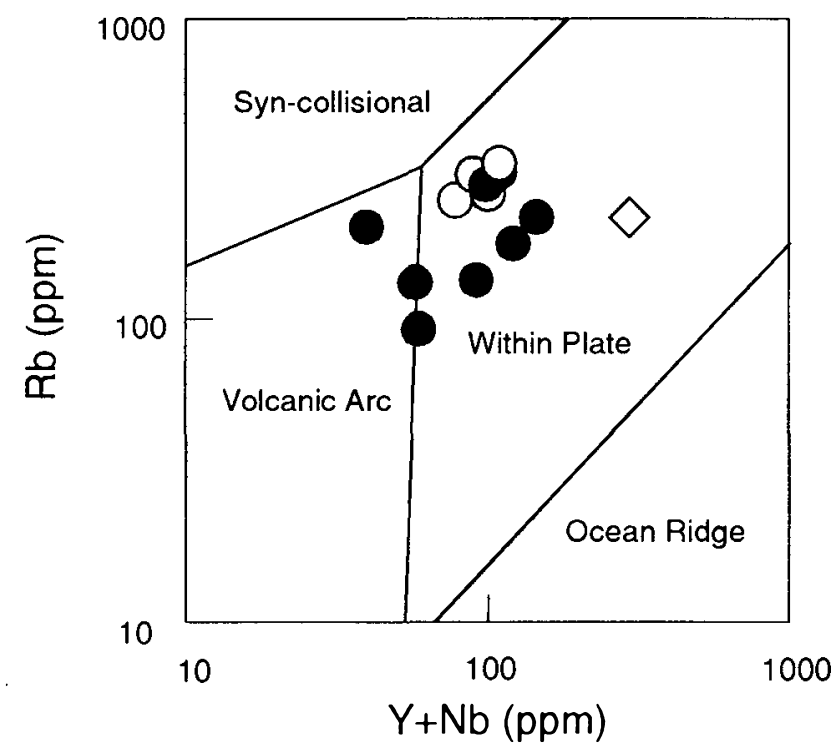

Fig. 11. Tectonic setting discrimination diagram for felsic samples from the Lake Ainslie and Gillanders Mountain areas, with fields from Pearce et al. (1984). A rhyolite sample (diamond symbol) from the Naivasha volcanic field in the Kenya Rift is shown for comparison (from Wilson, 1989, p. 348).

scale of Okulitch (1995), the age coincides with the boundary between the Middle and Late Devonian, placed at $375 \pm$ $6 \mathrm{Ma}$, and thus suggests that most of the Fisset Brook Formation in the Lake Ainslie - Gillanders Mountain area is Middle Devonian. The age is identical (within error) to that obtained from rhyolite in the type area of the Fisset Brook Formation (D. Piper, personal communication, 1995), demonstrating that the formation is the same age (Middle to earliest Late Devonian) in both areas. The age is also in agreement with fossil evidence reported by Blanchard $e t a l$. (1984) from the formation east of the type area. However, it 


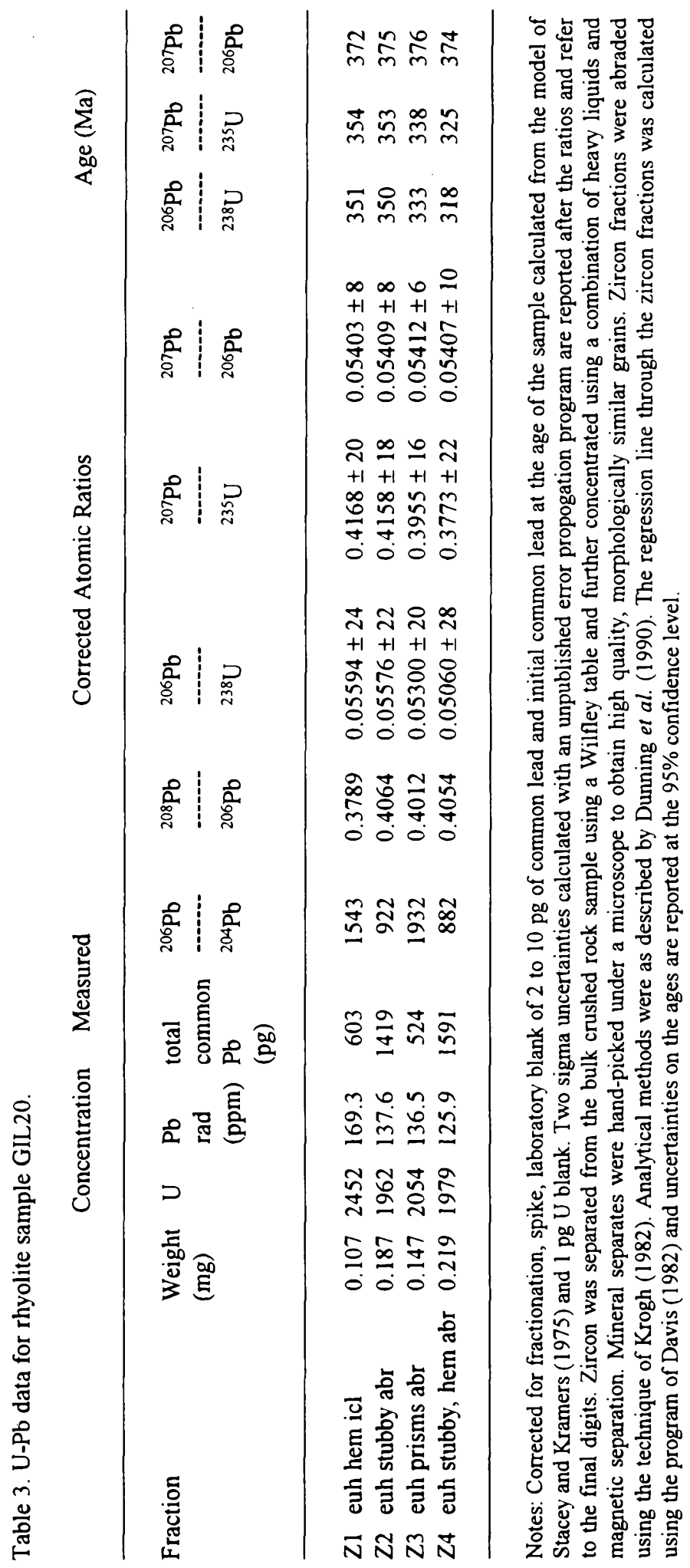

is not in agreement with the Rb-Sr data of Huard (1984) and the fossil evidence from the type section reported by Kelley and Mackasey (1965).

\section{Tectonic SetTing}

The petrochemical data presented here confirm that the Fisset Brook Formation in the Lake Ainslie - Gillanders

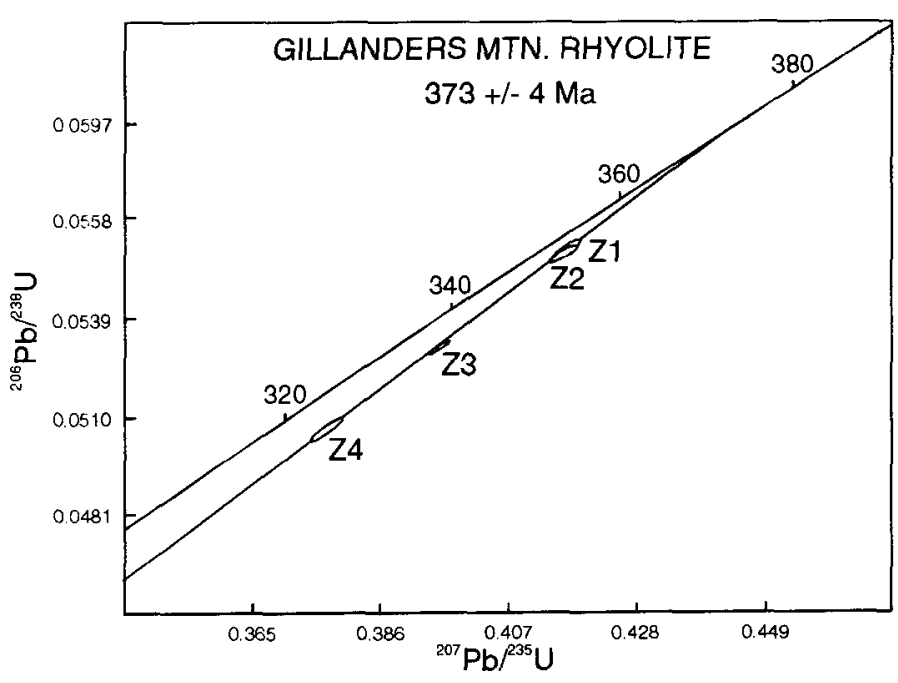

Fig. 12. Concordia diagram based on data in Table 3 .

Mountain area originated in a within-plate continental setting, as previously suggested for the formation as a whole (e.g., Blanchard et al., 1984). The Fisset Brook Formation is comparable to other bimodal subaerial volcanic rocks and associated, mainly non-marine sedimentary rocks formed at widespread locations throughout Atlantic Canada during the Late Silurian through Early Carboniferous, (e.g., Dostal et al., 1983, 1989, 1994; Barr et al., 1985; Blanchard et al., 1984; Cormier et al., 1995; Piper et al., 1993). Granitic and gabbroic plutons and mafic dykes accompanied the volcanism at deeper crustal levels.

Various models have been proposed to explain the tectonic setting in the northern Appalachian Orogen during this time. Bradley (1982) proposed that the Magdalen Basin formed as the result of a large pull-apart basin following the Acadian Orogeny. Blanchard et al. (1984) suggested that the bimodal volcanic and interbedded sedimentary rocks of the Fisset Brook Formation were associated with the formation of post-Acadian successor basins related to the formation of the main Magdalen Basin. McCutcheon and Robinson (1987) suggested that the magmatism occurred as a result of crustal thickening following the Acadian Orogeny, with depression of the upper crust into areas of higher heat flow causing the production of mantle-derived magmas. The proposed sequence of events included deposition of a basal conglomerate overlain by bimodal volcanic rocks, followed by continued sedimentation.

More recently, Lynch and Tremblay (1992) proposed that the Fisset Brook Formation was the result of extensional collapse following the Acadian Orogeny. They suggested that the Fisset Brook Formation was deposited on the exhumed footwall during extension. Lynch et al. (1993a) further suggested that the volcanic rocks that formed during extension underwent some metamorphism, whereas the volcanic rocks that formed after extension are fresh and overlie chloritized and foliated basalt which grades down into chloritic mylonite. A discontinuous belt of mylonite and associated detachment faults extending south from Cheticamp to Gillanders Mountain, defined as the Margaree Shear Zone, was interpreted to mark 
the extensional locus between the Fisset Brook Formation and its crystalline infrastructure (Lynch and Tremblay, 1994). Our mapping in the Lake Ainslie and Gillanders Mountain areas during this study provided no evidence of mylonitization of the Fisset Brook Formation that would directly support the model of Lynch et al. (1993a) and Lynch and Tremblay $(1992,1994)$. However, mylonitic zones are common in the gneissic and dioritic rocks of the crystalline infrastructure, and a circa $0.3 \mathrm{~km}$ thick mappable mylonite unit is present in the northeastern part of Gillanders Mountain area (Lynch et al., 1993b) which projects at a low angle westwards through the infrastructure beneath the Fisset Brook Formation (Figs. $2,3)$. Low-angle detachment faults at the base of the formation were not recognized either, but their existence cannot be precluded entirely.

As argued by Lynch and Tremblay (1994), the size, complexity, and protracted age of the Maritimes Basin favour an overall mixed-mode of origin (Gibbs, 1987). With such a model, a sequence of tectonic events can be envisaged which might reconcile various models proposed for the evolution of the Maritimes Basin: (i) post-orogenic, regional extension in the Middle Devonian to Early Carboniferous resulting in deposition of the Fisset Brook Formation and Horton Group in north-south oriented rift environments; (ii) broad subsidence and deposition during Early to Late Carboniferous, and (iii) regional dextral shear, via strike-slip faulting, in the Late Carboniferous to Early Permian resulting in extensive, local modifications to the basin via off-sets, pullaparts, and push-ups.

\section{Conclusions}

This study has demonstrated that the rocks of the Fisset Brook Formation in the Lake Ainslie and Gillanders Mountain areas are exposed in different structural settings, but show many stratigraphic, lithological, and petrochemical similarities which apparently extend to the type area near Cheticamp. The volcanic rocks are a bimodal basalt-rhyolite suite which, although pervasively altered and enriched in alkali elements, is essentially tholeiitic in character. Associated with the volcanic suite are non-marine, mainly red clastic rocks which appear to have formed in alluvial fan and shallow lacustrine depositional environments. This association is compatible with a continental rift setting.

The age of the Fisset Brook Formation has been redefined in the Gillanders Mountain area as Middle to earliest Late Devonian on the basis of a U-Pb age of $373 \pm 4 \mathrm{Ma}$ from rhyolite in the upper part of the section.

The evolution of the structural features in the two areas, particularly the inferred changes from extensional to transpressional over an extended time interval between Middle Devonian and Late Carboniferous-Early Permian(?), appears to be compatible with a mixed mode of origin (Gibbs, 1987) for the Magdalen Basin. The common occurrence of baritefluorite mineralization in the Lake Ainslie area, and perhaps also of the pervasive alteration in the volcanic rocks of the Fisset Brook Formation as a whole, may be related to expulsion of brines from the basin during this transpressional event.

\section{ACKNOWLEDGements}

Financial support for this project came mainly from separate contracts to SMB and ASM through the Canada-Nova Scotia Cooperation Agreement on Mineral Development through the Geological Survey of Canada, supplemented by a Natural Sciences and Engineering Research Council of Canada Research Grant to SMB. We thank Peter Giles for sharing his ideas about the relationships between the Fisset Brook Formation and the Horton Group. We also thank journal reviewers G. Pe-Piper and M.C. Williamson, whose helpful comments led to significant improvements in the manuscript. We are also grateful to Colin Macdonald who provided invaluable advice and assistance in the preparation of the figures for this manuscript.

Arnotr, A.A. 1994. Petrology and geochemistry of the Fisset Brook Formation in the Gillanders Mountain area, Cape Breton Island, Nova Scotia. B.Sc. Honours thesis, Acadia University, Wolfville, Nova Scotia, 117 p.

Barr, S.M., Brisebois, D., and Macdonald, A.S. 1985. Carboniferous volcanic rocks of the Magdalen Islands, Gulf of St. Lawrence. Canadian Journal of Earth Sciences, 22, pp. 1679 1688.

Barr, S.M., Jamieson, R.A., and Raeside, R.P. 1992. Geology, Northern Cape Breton Island, Nova Scotia. Geological Survey of Canada, Map 1752A.

Barr, S.M., White, C.E., Cormier, C.F.M., and DunNing, G.R. 1994. Devonian-Carboniferous igneous and sedimentary rocks in southern Cape Breton island and Guysborough County, Nova Scotia. In Nova Scotia Mines and Energy Branches, Report 94-2, p. 62.

Blanchard, M.-C. 1982. Geochemistry and petrogenesis of the Fisset Brook Formation, Western Cape Breton Island, Nova Scotia. Unpublished M.Sc. thesis, Dalhousie University, Halifax, Nova Scotia, 225 p.

Blanchard, M.-C., Jamieson, R.A., and More, E.B. 1984. Late Devonian - Early Carboniferous volcanism in western Cape Breton Island, Nova Scotia. Canadian Journal of Earth Sciences, 21 , pp. 762-774.

Bradley, D.C. 1982. Subsidence in Late Paleozoic basins in the northern Appalachians. Tectonics, 1, pp. 107-123.

-.-- 1983. Tectonics of the Acadian Orogeny in New England and adjacent Canada. Journal of Geology, 91, pp. 381-400.

Cormier, R.F. and Kelley, D.G. 1964. Absolute age of the Fisset Brook Formation and the Devonian-Mississippian Boundary, Cape Breton Island, Nova Scotia. Canadian Journal of Earth Sciences, 1, pp. 159-166.

Cormier, C.F.M., Barr, S.M., and Dunning, G.R. 1995. Geological setting and petrochemistry of early Middle Devonian volcanic and gabbroic rocks in the Guysborough area, Nova Scotia. Atlantic Geology, 31, pp. 153-166.

Creed, R.M. 1968. Barite-fluorite mineralization at Lake Ainslie, Inverness County, Nova Scotia. Unpublished M.Sc. thesis, Dalhousie University, Halifax, Nova Scotia, 158 p.

Davis, D.W. 1982. Optimum linear regression and error estimation applied to U-Pb data. Canadian Journal of Earth Sciences, 19, pp. 2141-2149.

Dostal, J., KePPIE, J.D., and DUPUY, C. 1983. Petrology and geochemistry of Devono-Carboniferous volcanic rocks in Nova Scotia. Maritime Sediments and Atlantic Geology, 19, pp. 59-71.

Dostal, J., Wilson, R.A., and KePPIE, J.D. 1989. Geochemistry 
of Siluro-Devonian Tobique Volcanic belt in northern and central New Brunswick (Canada): tectonic implications. Canadian Journal of Earth Sciences, 26, pp. 1282-1296.

Dostal, J., Laurent, R., and Keppie, J.D. 1994. Late SilurianEarly Devonian rifting during transpression in the southern Gaspe Peninsula (Quebec): petrogenesis of volcanic rocks. Canadian Journal of Earth Sciences, 30, pp. 2283-2294.

Dunning, G.R., O'Brien, S.J., Colman-Sadd, S.P., Blackwood, R.F., Dickson, W.L., O'Neill, P.P., and KROGH, T.E. 1990. Silurian orogeny in the Newfoundland Appalachians. Journal of Geology, 98, pp. 895-913.

FrENCH, V.A. 1985. Geology of the Gillanders Mountain Intrusive Complex and satellite plutons, Lake Ainslie area, Cape Breton Island, Nova Scotia. Unpublished M.Sc. thesis, Acadia University, Wolfville, Nova Scotia, 237 p.

GiBBs, A.D. 1987. Development of extension and mixed-mode sedimentary basins. In Continental extensional tectonics. Edited by M.P. Coward, J.F. Dewey and P.L. Hancock. Geological Society of London, Special Publication 28, pp. 19. 33.

Giles, P.S., Hein, F.J., and Allen, T.L. 1995. Bedrock geology of Port Hood-Lake Ainslie (11K04, 11 K03, 11F13), Cape Breton Island, Nova Scotia. Geological Survey of Canada, Open File $x x x x, 1: 50,000$ map with marginal notes.

Hanson, G.N. 1980. Rare earth elements in petrogenetic studies of igneous systems. Annual Reviews of Earth and Planetary Science, 8, pp. 371-406.

Haskin, L.A., HASkin, M.A., and Frey, F.A. 1968. Relative and terrestrial abundances of the rare earths. In Origin and distribution of the elements. Edited by L.H. Aherns. Pergamon, Oxford, United Kingdom, pp. 889-912.

Huard, A.A. 1984. The Carboniferous volcanic rocks at Lake Ainslie, Nova Scotia: implications for tectonic regime and barite mineralization. B.Sc. thesis, St. Francis Xavier University, Antigonish, Nova Scotia.

Hughes, C.J. 1973. Spilites, keratophyres, and the igneous spectrum. Geological Magazine, 6, pp. 513-527.

Kelley, D.G. and Mackasey, W.O. 1965. Basal Mississippian volcanic rocks in Cape Breton Island, Nova Scotia. Geological Survey of Canada, Paper 64-34.

KePpIE, J.D. 1979. Geological map of Nova Scotia. Nova Scotia Department of Mines and Energy, scale 1:500,000.

KEPPIE, J.D. and SMITH, P.K. 1978. Compilation of isotopic age data of Nova Scotia. Nova Scotia Department of Mines, Report 78-4.

KROGH, T.E. 1982. Improved accuracy of U-Pb zircon ages by the creation of more concordant systems using an air abrasion technique. Geochimica et Cosmochimica Acta, 46, pp. 637-649.

LYNCH, J.V.G. and TREMBlaY, C. 1992. Imbricate thrusting, reverse-oblique shear, and ductile extensional shear in the Acadian Orogen, central Cape Breton Highlands, Nova Scotia. Current Research, Part D, Geological Survey of Canada, Paper 92-1D, pp. 91-100.

-.-.- 1994. Late Devonian - Carboniferous detachment faulting and extensional tectonics in western Cape Breton island, Nova Scotia, Canada. Tectonophysics, 238, pp. 55-69.

Lynch, G., Tremblay, C., and Rose, H. 1993a. Compressional deformation and extensional denudation of Early Silurian volcanic overlap assemblages in western Cape Breton Island, Nova Scotia. Current Research, Part D, Geological Survey of Canada, Paper 93-1D, pp. 103-110.

Lynch, G., Tremblay, C., and Rose, H. 1993b. Geological map $(1: 50,000)$ of Lake Ainslie area, Cape Breton Island, Nova
Scotia (11K3 and west 11K2). Geological Survey of Canada, Open File 2613.

MaCdonald, A.S. 1994. Structural environment of the Lake Ainslie baryte - fluorite veins, Cape Breton Island. Nova Scotia Department of Natural Resources, Mines and Energy branches, Report 94-2, p. 61.

McCutcheon, S.R. and Robinson, P.T. 1987. Geological constraints on the genesis of the Maritime Basin, Atlantic Canada. Canadian Society of Petroleum Geologists, Memoir 12, pp. 287-297.

MESCHEDE, M. 1986. A method of discriminating between different types of mid-ocean ridge basalts and continental tholeiites with the Nb-Zr-Y diagram. Chemical Geology, 56, pp. $207-$ 218.

Neale, E.R.W. 1964. Cape St. Lawrence map-area, Nova Scotia. Geological Survey of Canada, Map 1150A, 1" = 1 mile.

Norman, G.W.H. 1933. Lake Ainslie map-area, Nova Scotia. Geological Survey of Canada, Map 282A, 1" = 1 mile.

---- 1935. Lake Ainslie map-area, Nova Scotia. Geological Survey of Canada, Memoir 177, 103 p.

OkuLiтch, A.V. 1995. Geological time chart, 1995. Geological Survey of Canada, Open File 3040.

Pearce, J.A. 1982. Trace element characteristics of lavas from destructive plate boundaries. In Andesites: Orogenic Andesites and Related Rocks. Edited by R.S Thorpe. Wiley-Interscience, New York, pp. 525-548.

Pearce, J.A., Harris, N.B.W., and Tindle, A.G. 1984. Trace element discrimination diagrams for the tectonic interpretation of granitic rocks. Journal of Petrology, 25, pp. 956-983.

Piper, D.J.W., Pe-Piper, G., and Loncarevic, B.D. 1993. Devonian-Carboniferous igneous intrusions and their deformation, Cobequid Highlands, Nova Scotia. Atlantic Geology, 29 , pp. 219-232.

Shervals, J.W. 1982. Ti-V plots and the petrogenesis of modern and ophiolitic lavas. Earth and Planetary Science Letters, 59, pp. 101-118.

Smith, P.K. and MacDonald, A.S. 1981. The Fisset Brook Formation at Lowland Cove, Inverness County, Nova Scotia. Nova Scotia Department of Mines and Energy, Paper 81-1, $18 \mathrm{p}$.

Stacey, J.S. and Kramers, J.D. 1975. Approximation of terrestrial lead isotope evolution by a two-stage model. Earth and Planetary Science Letters, 26, pp. 207-221.

Whalen, J.B., Currie, K.L., and Chappell, B.W. 1987. A-type granites: geochemical characteristics, discrimination, and petrogenesis. Contributions to Mineralogy and Petrology, 95, pp. 407-419.

Williams, G.L., Fyffe, L.R., Wardle, R.J., Colman-Sadd, S.P., and Boenner, R.C. 1985. Lexicon of Canadian Stratigraphy, Volume VI, Atlantic Region.

WILSON, M. 1989. Igneous Petrogenesis: a global tectonic approach. Unwin Hyman Limited, United Kingdom, 466 p.

Winchester, J.A. and Floyd, P.A. 1976. Geochemical magma type discrimination: application to altered and metamorphosed basic igneous rocks. Earth Planetary Science Letters, 28, pp. $459-469$.

.... 1977. Geochemical discrimination of different magma series and their differentiation products using immobile elements. Chemical Geology, 20, pp. 325-343.

ZURowski, M. 1972. Barite-fluorite deposits of Lake Ainslie - an appraisal from an economic viewpoint. CIM Transactions, 75 , pp. $318-321$.

Editorial Responsibility: P. Giles and G.L. Williams 